\section{$2 \mathrm{P093}$}

還元型チトクロム酸化酵素の NO 結合構造と CO 結 合構造の精密化

O村本 和優 ${ }^{1}$ 、青山 浩 ${ }^{2}$ 、石田 訓康 ${ }^{1}$ 、合内毅 1 、青波里実 1、山下栄樹 3 、伊藤・新澤 恭子 1 、月原 富武 3 、吉川信也 1

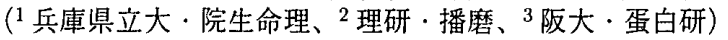

チトクロム酸化酵素は㟫元型のへム $a_{3}-\mathrm{Cu}_{B}$ サイトに酸素分子を結合 し水分子人と還元する。一酸化空素 (NO) や一酸化炭素 $(\mathrm{CO})$ も還元 型へム $a_{3}-\mathrm{Cu}_{B}$ サイトに配位し、これらは酸素還元反応を阻害する。 配位子の結合様式に関してはこれまでおもに分光学的に調べられて きたが、近年になりX 線構造解析が可能になった。以前の研究にお いて、CO 結合還元型については $2.8 \AA$ 分解能での常温構造の解析が 行われた。また最近の研究では、SPring8 BL44XUを用いて温度 100 $\mathrm{K}$ で $\mathrm{NO}$ 結合還元型と $\mathrm{CO}$ 結合還元型の $2.1 \dot{A}$ 分解能までの X 線回折 データが収集され、構造解析が行われている。ただし、低温構造では へム $a_{3}-\mathrm{Cu}_{B}$ サイトの $\mathrm{Fe}$ 原子と $\mathrm{Cu}$ 原子の電子密度に異方性があるた め、これまで配位子の構造精密化に問題があった。

本研究では低温構造での NO と CO の結合様式を明らかにするた め、電子密度の異方性を考慮して構造の精密化を行った。精密化計算 にはCCP4 プログラム Refmac5を使用し、TLS パラメーター、及び 異方性温度因子を含めて実行した。精密化計算後の差フーリエ電子 密度図により電子密度の異方性の補正を確認し、配位子の結合様式 について検討した。その結果、NOはへムの軸方向から傾いて Feに 配位していることが分かった。この結合様式は、他のへムタンパク質 での NOの結合様式と似たものであった。一方、 $\mathrm{CO}$ は Feよりも $\mathrm{Cu}$ に近い位置に結合していることが分かった。COの結合様式に関して は、可視吸収スペクトル測定や常温の構造との比較により更に検討を 行った。

K.Muramoto, H.Aoyama, K.Ishida, T.Kurauchi, S.Aonami, E.Yamashita, K.ShinzawaItoh, T.Tsukihara and S.Yoshikawa Structural refinement of the NO- and CO-coordination in cytochrome $c$ oxidase in the reduced state.

\section{P095}

Paracoccus denitrificans チトクロム $c$ 酸化酵素の $\mathrm{P}$ 中間体の性質と共鳴ラマンスペクトル

○池村 賢一郎 ${ }^{1}$ 、小合 尚志 ${ }^{1}$ 、向井 政博 ${ }^{2}$ 、島田 秀夫 ${ }^{2}$ 、吉 川信也 ${ }^{1}{ }^{1}$ 兵庫県立大院·生命理 $\cdot$ 生体物質、 ${ }^{2}$ 慶応大·医. 医化学)

チトクロム $c$ 酸化酵素 $(\mathrm{CcO})$ はミトコンドリア内膜に存在し、酸絜を 水にまで還元するとともに膜を隔てたプロトン輸送を行う。ウシ $\mathrm{CcO}$ の反応中間体である $\mathrm{P}$ 中間体は $607 \mathrm{~nm}$ の吸収と $804,356 \mathrm{~cm}^{-1}$ のラ マン線を与える。 $804 \mathrm{~cm}^{-1}$ は $\mathrm{Fe}=\mathrm{O}$ 伸繀振動に帰属されている。また $356 \mathrm{~cm}^{-1}$ は折れ曲がった His- $\mathrm{Fe}=\mathrm{O}$ 結合の変角振動之考えられており、 その構造変化がプロトン輸送の引き金になると示㖫されている。その 帰属をはっきりさせるためには ${ }^{15} \mathrm{~N}-\mathrm{H}$ is 置換体による同位体シフトを 観測する必要がある。そこで本研究ではParacoccus denitrificans 由 来の $\mathrm{CcO}$ (以下, $\mathrm{PDCcO}$ )の $\mathrm{P}$ 中間体の性質を調べた。Mixed-Valence $\mathrm{PDCcO}$ に酸素を加えると、607 nm に吸収極大を持つ P 中間体が生 成した。その半減期は $\mathrm{pH} 8.0$ で 260 分でありウシ $\mathrm{CcO}$ の 70 分に比 べて長かった。この $\mathrm{P}$ 中閭体の $590 \mathrm{~nm}$ 励起の共鳴ラマンスペクトル

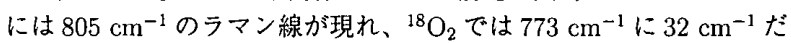
け低波数シフトした。これまでウシ $\mathrm{CcO}$ の $\mathrm{P}$ 中間体の $\mathrm{Fe}=\mathrm{O}$ 伸縮振 動モードはSoret 帯励起で検出されていたが、 $\alpha$ 帯励起でも観測しう ることがはっきりした。さらに、P中間体の共鳴ラマンスペクトル測 定に必要なタンパク量はナノモル程度であることがわかった。ゅえに ${ }^{15} \mathrm{~N}$-His ラベル体を作成して $356 \mathrm{~cm}^{-1}$ のラマン線を帰属する準備が 整った。

K. Ikemura, T. Ogura, M. Mukai, H. Shimada and S. Yoshikawa Resonance Raman Study on the P intermediate of Paracoccus denitrificans Cytchrome $c$ Oxidase

\section{$2 \mathrm{P} 094$}

共鳴ラマン分光法による無傷ミトコンドリア中のチ トクロム酸化酵素反応中間体の構造追跡

○高橋 俊成 ${ }^{1,2}$ 、小倉 尚志 ${ }^{2}$ 、吉川信也 ${ }^{2}{ }^{(1}$ 東大·院·総合 文化、 ${ }^{2}$ 兵庫県立大 $\cdot$ 院 $\cdot$ 理)

チトクロム酸化酵 $(\mathrm{CcO})$ はミトコンドリア電子伝達系の末端に 存在する醳素であり、酸素を水にまで邀元するとともに、これに共役 してプロトンのポンプを行っている。酸素還元反応における中間体の 構造は、時間分解共鳴ラマン分光法をはじめとする方法により決定さ れてきた。しかし、これまでは可溶化 $\mathrm{CcO}$ を用いた研究がはとんど であった。ミトコンドリア膜中に存在する場合と可溶化した場合では 周囲の環境が違い、構造が翼なる可能性が大きい。

そこで、本研究では、無㰾ミトコンドリアを用い、膜中における $\mathrm{CcO}$ の反応中間体の構造変化を時間分解共鳴ラマン分光法を用いて追 跡した。ラマン散乱の励起には $423 \mathrm{~nm}$ のレーザーを用いた。人工心 肺装置*を用いることにより、可溶化 $\mathrm{CcO} に お い て 、 571 ~ \mathrm{~cm}^{-1}, 804$ $\mathrm{cm}^{-1}, 785 \mathrm{~cm}^{-1}$ に出現する酸素化型, パーフェリル型, フェリル型 に由来するバンドを観測することに成功した。現在のところ、これら のバンドの振動数は可溶化 $\mathrm{CcO}$ と大きな違いは見られていないもの の、陦命は若下長くなる傾向が見られた。また、ヒドロキシ型中間体 は現在のところ観測されていないが、測定を行った時間領域は反応開 始後 $2 \mathrm{~ms}$ までであり、これ以降の時間領域でヒドロキシ型中間体が 生成していると考えられる。以上の結果から、酸素の還元反応におけ る反応中間体がミトコンドリア中でも生成することが確認された。こ れは、これまで可溶化 $\mathrm{CcO}$ で議論されてきた酸素還元機構が生体内 においても実際に起こっていることを支持する結果となった。

*T. Ogura, S. Takahashi, S. Hirota, K. Shinzawa-Itoh, S. Yoshikawa, E.H. Appelman and T. Kitagawa (1993) J.Am.Chem. Soc., 115, 8527-8536

T.Takahashi, T.Ogura and S.Yoshikawa : Resonance Raman spectroscopy of reaction intermediates of cytochrome $c$ oxidase in intact mitochondria

\section{$2 \mathrm{P} 096$}

Detection of the primary ferrous nitrosyl heme intermediate in the reduction of $\mathrm{NO}$ by cytochrome $b a_{3}$ oxidase

○ Varotsis Costas ${ }^{1}$ 、太田 雄大 ${ }^{2}$ 、北川 禎三 ${ }^{2}$ 、Daskalakis Vangelis 1 、Gialou Irene ${ }^{1}$, Soulimane Tewfik ${ }^{3} 、$ Pinakoulaki Eftychia ${ }^{1} \quad\left({ }^{1}\right.$ Univ. of Crete, Dept. of Chem.、 ${ }^{2}$ 自然機構 - 岡崎 統合バイオ、 ${ }^{3}$ Paul Scherrer Institute)

The thermophilic Gram-negative eubacterium Thermus thermophilus HB8 (ATCC27634) expresses $c a a_{3}$ - and $b a_{3}$ - cytochrome oxidases. Both enzymes catalyze the reduction of $\mathrm{O}_{2}$ to $\mathrm{H}_{2} \mathrm{O}$ and translocate protons across the inner bacterial membrane. In addition both enzymes catalyze the reduction of $\mathrm{NO}$ to $\mathrm{N}_{2} \mathrm{O}$ and the oxidation of $\mathrm{CO}$ to $\mathrm{CO}_{2}$. Proposed reaction pathways for the catalytic cycles are difficult to verify without the structure of the intermediates, but we now have such information on the primary intermediate in the reaction of $b a_{3}$-cytochrome oxidase with NO from resonance Raman spectroscopy. We have identified the primary His-heme $a_{3}{ }^{2+}-\mathrm{NO} /$ $\mathrm{Cu}_{B}{ }^{1+}$ species by its characteristic Fe-NO and N-O stretching frequencies at 539 and $1620 \mathrm{~cm}^{-1}$, respectively. The characteristics of the nitrosyl species have a rationale in terms of the $\mathrm{Fe}\left(\mathrm{d}_{\pi}\right)-\mathrm{NO}(\pi$ *) bonding and are fully supported by density functional theory calculations (DFT). We show by time-resolved FTIR spectroscopy that $\mathrm{Cu}_{B}{ }^{1+}$ has a much lower affinity for NO than for $\mathrm{CO}$. With the identification of the primary nitrosyl intermediate in which the $\mathrm{O}$ atom is not hydrogen-bonded the predominant structure of the primary intermediate is known. The initial steps in the formation of the sixcoordinate nitrosyl intermediate in $b a_{3}$-cytochrome oxidase are compared with those of the five coordinate nitrosyl species obtained in $\mathrm{Caa}_{3}$ oxidase, and discussed in terms of the catalytic pathway for the conversion of $\mathrm{NO}$ to $\mathrm{N}_{2} \mathrm{O}$ by the bona fide $\mathrm{NO}$ reductases.

C.Varotsis, T.Ohta, T.Kitagawa, V.Daskalakis, I.Gialou, T.Soulimane, and E.Pinakoulaki : Detection of the primary ferrous nitrosyl heme intermediate in the reduction of NO by cytochrome $b a_{3}$ oxidase from Thermus thermophilus 